\title{
Soap Dosage Form
}

National Cancer Institute

\section{Source}

National Cancer Institute. Soap Dosage Form. NCI Thesaurus. Code C42983.

An anionic surfactant for cleansing. 